\title{
Redox supercapacitor performance of nanocrystalline molybdenum nitrides obtained by ammonolysis of chloride- and amide-derived precursors
}

\author{
S. Imran U. Shah, Andrew L. Hector* and John R. Owen \\ Chemistry, University of Southampton, Highfield, Southampton SO17 1BJ, UK \\ * Correspondence to A.L.Hector@ soton.ac.uk
}

\begin{abstract}
Reactions of $\mathrm{MoCl}_{5}$ or $\mathrm{Mo}\left(\mathrm{NMe}_{2}\right)_{4}$ with ammonia result in cubic $\gamma-\mathrm{Mo}_{2} \mathrm{~N}$ or hexagonal $\delta_{1}-\mathrm{MoN}$ depending on reaction time and temperature. At moderate temperatures the cubic product from $\mathrm{Mo}\left(\mathrm{NMe}_{2}\right)_{4}$ exhibits lattice distortions. Fairly high surface areas are observed in the porous particles of the chloride-derived materials and high capacitances of up to $275 \mathrm{~F} \mathrm{~g} \mathrm{~g}^{-1}$ are observed when electrodes made from them are cycled in aqueous $\mathrm{H}_{2} \mathrm{SO}_{4}$ or $\mathrm{K}_{2} \mathrm{SO}_{4}$ electrolytes. The cyclic voltammograms suggest charge is largely stored in the electrochemical double layer at the surface of these materials. Amide-derived molybdenum nitrides have relatively low surface areas and smaller capacitances, but do exhibit strong redox features in their cyclic voltammograms, suggesting that redox capacitance is responsible for a significant proportion of the charge stored.
\end{abstract}

\section{Highlights:}

- Hexagonal $\delta_{1}-\mathrm{MoN}<500{ }^{\circ} \mathrm{C}$ or cubic $\gamma-\mathrm{Mo}_{2} \mathrm{~N}>600{ }^{\circ} \mathrm{C}$ from a $\mathrm{MoCl}_{5}$-derived polymer.

- High double layer capacitance in aqueous electrolyte with good cycling stability.

- Phase behaviour of molybdenum nitride from a $\mathrm{Mo}\left(\mathrm{NMe}_{2}\right)_{4}$-derived polymer.

- Good capacitance and stable cycling in relatively low surface area materials.

- Redox peaks in the electrochemical data suggesting a largely redox-based process.

Keywords: molybdenum, nitride, supercapacitor, double layer, redox 


\section{Introduction}

The most studied nitrides of molybdenum are the rocksalt-type $\gamma-\mathrm{MoN}_{\mathrm{x}}$, with $\mathrm{x}$ typically between 0.39 and 0.54 (hence often labelled as $\gamma-\mathrm{Mo}_{2} \mathrm{~N}$ ) and disordered nitrogen vacancies [1], and the hexagonal phases $\delta_{1}$-MoN (WC type, $P$ - $6 m 2$ ), $\delta_{2}$-MoN (NiAs-type, $P 6_{3} / m m c$ ) and $\delta_{3}$-MoN (FeStype, $P 6_{3} m c$ ) with compositions close to stoichiometry (Fig 1) [2,3]. The $\alpha$-phase is molybdenum metal with small amounts of dissolved nitrogen, whereas $\beta-\mathrm{Mo}_{2} \mathrm{~N}$ is tetragonally distorted rocksalttype with ordered stacking faults, and requires careful control of conditions for its synthesis [4,5], and $\mathrm{Mo}_{5} \mathrm{~N}_{6}$ has been obtained by ammonolysis of molybdenum sulfide [6].

Much of the interest in molybdenum nitrides in recent years stems from their catalytic activity for ammonia synthesis [4], NO decomposition [7], alkane hydrogenolysis and dehydrogenation [8], hydrodesulphurisation [9] and hydrodenitrogenation [10]. They have been investigated for their corrosion resistance [11], superconductivity [12], wear resistance [13], diffusion resistance [14] and electrocatalytic activity in the hydrogen evolution reaction [15]. The charge storage capability of metal nitrides in electrochemical capacitor ("supercapacitor") electrodes has grown in importance recently due to reports of high capacities in some materials [16], e.g. with nanocrystalline VN Choi et al found a specific capacity of $1340 \mathrm{~F} \mathrm{~g}^{-1}$ at $2 \mathrm{mV} \mathrm{s}^{-1}$ and $554 \mathrm{~F} \mathrm{~g}^{-1}$ at $100 \mathrm{mV} \mathrm{s}^{-1}$ in aqueous $\mathrm{KOH}$ electrolyte [17]. $\mathrm{Mo}_{2} \mathrm{~N} / \mathrm{MoN}$ films produced by ammonolysis of $\mathrm{MoO}_{3}$ were first investigated as supercapacitor electrode materials by Finello, Roberson and Conway in the 1990s $[18,19,20]$. These compounds were found to be stable in aqueous $\mathrm{H}_{2} \mathrm{SO}_{4}$ and to exhibit redox behaviour similar to that of $\mathrm{RuO}_{2}$, but the smaller electrochemical window of $\sim 0.6 \mathrm{~V}$ compared with the $\sim 1.4 \mathrm{~V}$ of $\mathrm{RuO}_{2}$ was considered to limit their capability. Chen et al showed that an unidentified polycrystalline composite material formed by ammonolysis of a molybdenum/tantalum oxide mixture had higher capacity than molybdenum nitride produced under the same conditions [21]. Later the same group used temperature programmed reduction of $\mathrm{MoO}_{3}$ to produce $16 \mathrm{~nm} \gamma$ MoN crystallites and found both a high specific capacitance $\left(172 \mathrm{~F} \mathrm{~g}^{-1}\right)$ and an increased potential window $(1.1 \mathrm{~V})$ [22]. Choi et al reacted $\mathrm{MoCl}_{5}$ in chloroform with ammonia then heated the precipitate in ammonia to make $\gamma$-MoN with $\sim 110 \mathrm{~F} \mathrm{~g}^{-1}$ capacity at $2 \mathrm{mV} \mathrm{s}^{-1}$ but poorer performance at faster rates and $\sim 40 \%$ loss of capacity over 500 cycles [23]. Recently Lee et al used ammonolysis of single crystal $\mathrm{MoO}_{3}$ nanowires to make mesoporous $\mathrm{Mo}_{3} \mathrm{~N}_{2}$ wires which exhibited higher capacities than the same material made from commercial $\mathrm{MoO}_{3}$ and maintained a capacity over $200 \mathrm{~F} \mathrm{~g}^{-1}$ even at a charge/discharge rate of $200 \mathrm{mV} \mathrm{s}^{-1}$ [24].

Synthesis of molybdenum nitrides commonly involves heating a suitable precursor material in ammonia including the metal [25] and $\mathrm{MoCl}_{5}[2,26,27]$, whereas carefully controlled ammonolysis 
of $\mathrm{MoO}_{3}[5,28]$ and various other oxide-containing materials $[29,30]$ have been used to obtain high surface area materials suitable for catalysis. Vapour phase deposition methods for films are also well developed [14,31], and high pressure has been used in a number of cases to obtain stoichiometry or more crystalline products [3,32]. Whilst the catalysis interest has led to significant reports of high surface area and thus nanocrystalline materials, there are only a small number of reports of the synthesis of anisotropic molybdenum nitride structures [33]. Nanorods have been obtained via the topotactic transformation of $\mathrm{MoO}_{3}$ nanorods [4,24], templated growth in porous alumina [29], solvothermal synthesis from $\mathrm{MoCl}_{5}$ and $\mathrm{LiNH}_{2}$ [34] and in composites with silicon nitride using sol-gel methods [35]. Nanotubes have been obtained by topotactic ammonolysis of hydrothermally prepared molybdenum sulfide nanotubes [36], and by atomic layer deposition onto the internal walls of anodised aluminium oxide followed by dissolution of the template [37].

In this paper we report solution phase ammonolysis reactions of $\mathrm{MoCl}_{5}$ and $\left[\mathrm{Mo}\left(\mathrm{NMe}_{2}\right)_{4}\right]$ to form polymeric precursors, and their decomposition in ammonia at high temperature to produce molybdenum nitrides in nanocrystalline, nanorod and nanotube form. The surprising finding is that the two precursors result in very different molybdenum nitride phase behaviours. Our general interest in such reactions stems from the potential to access higher metal oxidation states [38,39,40] and to make controlled material morphologies [41]. Herein we targeted small particle molybdenum nitride samples that may act as good charge storage materials and tested their performance as electrodes in aqueous electrochemical capacitors. One set of materials exhibited charge storage behaviour consistent with a mainly double layer based mechanism whereas the other set had significant redox properties.

\section{Experimental}

All reagents and products were handled under nitrogen using glove box or Schlenk line methods. $\mathrm{MoCl}_{5}(99.6 \%),{ }^{\mathrm{n}} \mathrm{BuLi}$ (1.6 $\mathrm{M}$ in hexanes) and $\mathrm{Me}_{2} \mathrm{NH}(99+\%)$ were purchased from Aldrich and used as supplied. Solvents were dried by distillation from sodium/benzophenone. Liquid ammonia was distilled from $\mathrm{Na} / \mathrm{ammonia}$ solution, and gaseous ammonia was dried by passing through a column of pre-dried $4 \AA$ molecular sieves. $\mathrm{Mo}\left(\mathrm{NMe}_{2}\right)_{4}$ was prepared according to a literature procedure ${ }^{42}$ and checked for purity by ${ }^{1} \mathrm{H}$ NMR $\left(\delta: 3.273\right.$ ppm in $\left.\mathrm{C}_{6} \mathrm{D}_{6}\right)$ and combustion microanalysis. Polymer syntheses proceeded as follows:

1) $\mathrm{MoCl}_{5}(2 \mathrm{~g})$ was dissolved in $\mathrm{n}$-hexane $\left(20 \mathrm{~cm}^{3}\right)$. Liquid $\mathrm{NH}_{3}\left(20 \mathrm{~cm}^{3}\right)$ was condensed into the stirred solution at $-78{ }^{\circ} \mathrm{C}$. A bright yellow precipitate appeared on first exposure of the solution to 
ammonia, which turned brown and then black as the ammonia was allowed to evaporate and the temperature approached ambient. The molybdenum chloroimide polymer was collected by filtration and dried in vacuo (yield $\sim 2.5 \mathrm{~g}$ ).

2) $\left[\mathrm{Mo}\left(\mathrm{NMe}_{2}\right)_{4}\right](0.5 \mathrm{~g})$ was dissolved in tetrahydrofuran $\left(\mathrm{THF}, 10 \mathrm{~cm}^{3}\right)$. Liquid $\mathrm{NH}_{3}\left(10 \mathrm{~cm}^{3}\right)$ was condensed into the stirred solution at $-78^{\circ} \mathrm{C}$, during which time the purple amide solution yielded a black precipitate. The black molybdenum imide polymer was collected by filtration and dried in vacuo (yield $\sim 0.3 \mathrm{~g}$ ).

Polymers were loaded into dry alumina boats and then into silica furnace tubes equipped with an arrangement of Teflon taps that allow them to be loaded in the glove box and all hoses to be flushed before exposing samples to the gas flow. Samples were heated under flowing dry ammonia at temperatures and for time periods given later. The chloroimide polymer pyrolysis yields $\mathrm{NH}_{4} \mathrm{Cl}$ as a by-product, this was collected in a roll of aluminium foil placed outside the furnace hot zone in order to avoid contamination of the product. The molybdenum nitride products were obtained as black powders.

Powder X-ray diffraction (PXD) patterns were collected with a Siemens D5000 diffractometer using $\mathrm{Cu}-\mathrm{K}_{\alpha 1}$ radiation and Rietveld refinements [43] were performed using the GSAS package with standard structures taken from the Inorganic Crystal Structure Database (ICSD) [44] and crystallite sizes calculated as described in the GSAS manual. Thermogravimetric analyses (TGA) employed a Mettler Toledo TGA/SDTA851e with a ramp rate of $10{ }^{\circ} \mathrm{C} / \mathrm{min}$ under an $\mathrm{N}_{2}$ flow rate of $50 \mathrm{ml} / \mathrm{min}$ (Air Products BiP grade). Transmission electron microscopy (TEM) was performed with a Hitachi H7000 using $75 \mathrm{kV}$ accelerating voltage on samples dispersed into dry solvent and deposited onto carbon grids. Infrared (IR) spectra were collected on CsI disks using a Perkin Elmer Spectrum One. Combustion microanalysis $(\mathrm{C}, \mathrm{H}, \mathrm{N})$ and Schöniger flask combustion analysis $(\mathrm{Cl})$ measurements were outsourced to Medac Ltd (Chobham, Surrey). Nitrogen adsorption-desorption isotherms were collected using a Micromeritics Gemini 2375, and surface areas and pore size distributions were calculated using the BET and BJH methods (respectively) [45].

Molybdenum nitride electrodes were made using an ink prepared by grinding together the active material (75 wt\%), acetylene black carbon (20\%) and a polyvinylidene difluoride (PVDF) binder (5\%). The PVDF was dissolved in cyclopentanone $\left(1.5 \mathrm{~cm}^{3}\right.$ per $100 \mathrm{mg}$ total electrode material) under stirring for $2 \mathrm{~h}$ then the active material and carbon were added and the mixture stirred overnight. Titanium foil (0.05 mm thickness) was cleaned with fine abrasive paper, washed with ethanol, dried and then cut into $1.5 \times 2.5 \mathrm{~cm}$ pieces. The ink was coated onto $1 \mathrm{~cm}$ of the foil making a $1.5 \mathrm{~cm}^{2}$ area, and left to dry first in air and then overnight under vacuum at $120^{\circ} \mathrm{C}$. The 
mass of electrode material ( $2 \mathrm{mg}$ ) was determined by difference. Cyclic voltammograms were collected using a Biologics SP150 potentiostat with degassed $0.5 \mathrm{~mol} \mathrm{dm}{ }^{-3} \mathrm{H}_{2} \mathrm{SO}_{4(\mathrm{aq})}$ or $\mathrm{K}_{2} \mathrm{SO}_{4(\mathrm{aq})}$ electrolyte, a $\mathrm{Hg} / \mathrm{HgSO}_{4}$ reference electrode filled with the electrolyte in use for the experiment and high surface area platinum mesh counter electrode. Each electrode was initially scanned from the open circuit potential to the positive limit (various potential ranges used) and cycled between this and a negative potential limit at a number of rates (10 cycles each at $100,25,10$ and $2 \mathrm{mV} \mathrm{s}$ followed by 100 cycles at $100 \mathrm{mV} \mathrm{s}^{-1}$, all under $\mathrm{N}_{2}$ atmosphere). Specific capacitance was calculated as half of the integral of the $\mathrm{CV}$ trace divided by (scan rate $\times$ potential window $\times$ mass of active material). Use of a reference electrode negates the effect of the surface area of the counter electrode. Electrodes were inspected after cycling and visually retained their original condition.

\section{Results and discussion}

Solution phase ammonolysis of molybdenum chloride or dimethylamide is expected to lead to polymeric precipitates containing amide and imide groups due to transamination of the metal centres followed by condensation reactions between metal centres:

$\mathrm{MoCl}_{5}+\mathrm{a} \mathrm{NH}_{3} \rightarrow\left[\mathrm{MoCl}_{\mathrm{x}}\left(\mathrm{NH}_{2}\right)_{\mathrm{y}}(\mathrm{NH})_{\mathrm{z}}\right]_{\mathrm{n}}+\mathrm{b} \mathrm{NH} \mathrm{NH}_{4} \mathrm{Cl}$

$\left[\mathrm{Mo}\left(\mathrm{NMe}_{2}\right)_{4}\right]+\mathrm{a} \mathrm{NH}_{3} \rightarrow\left[\mathrm{Mo}\left(\mathrm{NMe}_{2}\right)_{\mathrm{x}}\left(\mathrm{NH}_{2}\right)_{\mathrm{y}}(\mathrm{NH})_{\mathrm{z}}\right]_{\mathrm{n}}+\mathrm{b} \mathrm{HNMe}_{2}$

The reactions of $\mathrm{MoCl}_{5}$ with $\mathrm{NH}_{3}$ in the solid state have previously been found to suffer from melting of the $\mathrm{MoCl}_{5}$ which results in large, low surface area spherical $\delta_{1^{-}}$, mixed $\gamma / \delta_{1^{-}}$or $\delta_{3}$-MoN particles depending on temperature. ${ }^{27}$ Others have found that lowered ammonia concentrations can be used to favour formation of $\gamma-\mathrm{Mo}_{2} \mathrm{~N}$ at lower temperatures and to obtain phase pure samples, ${ }^{26}$ and in the same study a high pressure ammonothermal route was used to obtain $\gamma-\mathrm{Mo}_{2} \mathrm{~N}$ directly. Solution phase ammonolysis avoids direct heating of the low-melting and volatile chloride or amide precursors and hence gives the opportunity to target small particle sizes. Ammonolysis of $\mathrm{MoCl}_{5}$ in chloroform followed by heating in ammonia at $600-800{ }^{\circ} \mathrm{C}$ yielded $\gamma-\mathrm{Mo}_{2} \mathrm{~N}$ [23]. Only one example of such a reaction based on a metal amide has been reported previously, where ammonolysis of $\left[\mathrm{Mo}_{2}\left(\mathrm{NMe}_{2}\right)_{6}\right]$ in THF was found to be very slow, but to yield a polymeric precursor that decomposes to $\gamma-\mathrm{Mo}_{2} \mathrm{~N}$ at $450{ }^{\circ} \mathrm{C}$ [38]. [ $\left.\mathrm{Mo}\left(\mathrm{NMe}_{2}\right)_{4}\right]$ can be produced with higher yields than $\left[\mathrm{Mo}_{2}\left(\mathrm{NMe}_{2}\right)_{6}\right]$ and has been used in CVD of amorphous molybdenum nitride [14], hence in this study we have compared the solution phase ammonolysis of $\mathrm{MoCl}_{5}$ with that of $\left[\mathrm{Mo}\left(\mathrm{NMe}_{2}\right)_{4}\right]$ and then gone on to examine the electrochemical charge storage capacity of molybdenum nitride materials formed by heating the resultant polymers at a wide range of temperatures. 


\subsection{Characterisation of the polymeric precursors}

The chloroimide polymer precursor obtained from the reaction of $\mathrm{MoCl}_{5}$ and ammonia contains significant amounts of $\mathrm{NH}_{4} \mathrm{Cl}$ and some solvent with an overall composition $\mathrm{MoC}_{0.2} \mathrm{H}_{15.5} \mathrm{~N}_{4.8} \mathrm{Cl}_{1.2}$. The IR spectrum shows a broad strong band at $3150 \mathrm{~cm}^{-1}\left(v_{\mathrm{NH}}\right)$ and a strong, sharp band at $1599 \mathrm{~cm}^{-}$ ${ }^{1}\left(\delta_{\mathrm{NH} 2}\right)$ and weak bands at 3048 and $2826\left(v_{\mathrm{CH}}\right)$, and $2000-800 \mathrm{~cm}^{-1}$. The TGA profile (Fig. 2) shows $\sim 20 \%$ mass loss below $300{ }^{\circ} \mathrm{C}$ due to sublimation of $\mathrm{NH}_{4} \mathrm{Cl}$ then steady loss to a plateau around $600{ }^{\circ} \mathrm{C}$ and a further steady mass loss to $800{ }^{\circ} \mathrm{C}$. In total it loses $74 \%$ of mass over this temperature range.

The IR spectrum of the imide polymer precursor shows a strong, broad band at $3245 \mathrm{~cm}^{-1}\left(v_{\mathrm{NH}}\right)$, a sharper strong band at $850 \mathrm{~cm}^{-1}\left(v_{\mathrm{MoN}}\right)$ and weaker features at 2930-2760 $\left(v_{\mathrm{CH}}\right)$ and $1605 \mathrm{~cm}^{-1}$ $\left(\delta_{\mathrm{NH} 2}\right)$. Combustion analysis yielded a composition of $\mathrm{MoC}_{0.92} \mathrm{H}_{4.61} \mathrm{~N}_{2.15}$. The TGA trace shows a gradual mass loss up to $800{ }^{\circ} \mathrm{C}$, with the mass loss accelerating above $700{ }^{\circ} \mathrm{C}$, probably due to thermal decomposition of the nitride products. Baxter et al used mass spectrometry to examine exhaust gases from TGA of metal amide-derived materials, and found dual weight loss profiles for many metals corresponding mainly to condensation reactions before the plateau (amine and ammonia loss) and reduction of the metal (nitrogen loss) after the plateau. ${ }^{38}$ This is similar to the profile obtained with the chloroimide polymer if the ammonium chloride loss feature is discounted. Similarly to our $\left[\mathrm{Mo}\left(\mathrm{NMe}_{2}\right)_{4}\right]$-derived imide polymer results, the $\left[\mathrm{Mo}_{2}\left(\mathrm{NMe}_{2}\right)_{6}\right]$-derived polymers had a barely discernable plateau, and this can be attributed to the lower initial oxidation state and the wide stoichiometry ranges exhibited by the molybdenum nitrides.

\subsection{Pyrolysis of the chloroimide polymer precursor}

Heating the chloroimide in flowing ammonia resulted in the formation of either the $\delta_{1}-\mathrm{MoN}$ $\left(500{ }^{\circ} \mathrm{C}\right)$ or $\gamma-\mathrm{Mo}_{2} \mathrm{~N}\left(700-1000{ }^{\circ} \mathrm{C}\right)$ phases as shown in Fig. 3. Choi and Kumta found $\gamma-\mathrm{Mo}_{2} \mathrm{~N}$ from a similar polymer between 600 and $800{ }^{\circ} \mathrm{C}$ [23]. Removal of the $\mathrm{NH}_{4} \mathrm{Cl}$ by-product by sublimation onto aluminium foil was found to be effective, no ammonium chloride reflections were observed. Rietveld refinements were carried out where the peaks were well enough defined to allow them and the resulting lattice parameters are listed in Table 1. Reported lattice parameters for $\gamma-\mathrm{Mo}_{2} \mathrm{~N}$ vary from 4.16 to $4.22 \AA$ and all our values fit within this range, with the variation consistent with the known compositional variations that can occur in this phase $[3,44]$. Literature lattice parameters for $\delta_{1}$-MoN are in the more tightly defined range of $a=2.86(1)$ and $c=2.79(2) \AA$ $[2,27]$, again our values fall in this range. 
Combustion analyses (Table 1) show the hexagonal $\delta_{1}-\mathrm{MoN}$ samples made at $500{ }^{\circ} \mathrm{C}$ to be largely close to stoichiometric with a small amount of chloride impurity. The mixed $\delta_{1}-\mathrm{MoN} / \gamma-\mathrm{Mo}_{2} \mathrm{~N}$ sample made at $600{ }^{\circ} \mathrm{C}$ remains stoichiometric, chloride being present below the analysis threshold ( $\sim 0.1 \%)$. Samples prepared at higher temperatures were found to be lower in nitrogen content, but nonetheless nitrogen-rich compared with the $\gamma-\mathrm{Mo}_{2} \mathrm{~N}$ formulation. This rocksalt-type phase varies widely in stoichiometry but our measured compositions are richer in nitrogen that the phases listed in ICSD [44]. Only the hexagonal samples made at $500{ }^{\circ} \mathrm{C}$ had high surface areas, and even at this low temperature the surface area decreased with heating time. All of these samples exhibited broad pore size distributions in the range $\sim 5-20 \mathrm{~nm}$ and hence they can be characterised as mesoporous materials.

IR spectra featured a broad background as expected from the metallic properties of these samples and a weak, broad peak at 3430-3450 $\mathrm{cm}^{-1}$ consistent with residual surface NH groups due to the synthesis in ammonia - clearly these are at too low a concentration to be detected in the combustion analyses.

Scanning electron microscopy revealed large, porous aggregates at all temperatures (Fig. 4), which give the impression that the pores are formed during synthesis, probably from the sublimation of the $\mathrm{NH}_{4} \mathrm{Cl}$ by-product. The diffraction peak widths suggest crystallite sizes to be fairly constant at $\sim 20$ $\mathrm{nm}$ across the range of synthesis temperatures studied, but TEM images (Fig. 4) show low temperature synthesis to result in rod-shaped crystallites where the longest axis is the $\sim 20 \mathrm{~nm}$ observed in the diffraction, whereas at higher temperatures these crystallites are much more isotropic. This explains why the surface areas vary significantly despite the very similar crystallite sizes.

\subsection{Pyrolysis of the imide polymer precursor}

Pyrolysis in ammonia of the imide polymer (that was derived from reaction of $\mathrm{Mo}\left(\mathrm{NMe}_{2}\right)_{4}$ and ammonia) at temperatures up to $900{ }^{\circ} \mathrm{C}$ resulted in samples that gave broad, rocksalt-like reflections. In direct contrast to the samples produced from the chloroimide polymer, hexagonal MoN was only observed at high temperatures. Samples produced at low temperature were observed to exhibit a structural distortion from cubic geometry. At $900{ }^{\circ} \mathrm{C}$ all of the rocksalt peaks can be indexed using the cubic unit cell of $\gamma-\mathrm{Mo}_{2} \mathrm{~N}$, but Fig. 5 shows that peak positions do not maintain this cubic geometry at lower temperature, specifically the angle between the 111 and 200 reflections becomes larger. This type of distortion has been previously observed in $\mathrm{Hf}_{3} \mathrm{~N}_{4}$, where it was initially described in terms of a rhombohedrally distorted defect rocksalt lattice [46] and later found to be due to a tetragonally distorted defect fluorite lattice [40]. No specific distortion was found that 
modelled these molybdenum nitride samples well. The sample produced by annealing at $500{ }^{\circ} \mathrm{C}$ for $48 \mathrm{~h}$ is especially interesting as it is stoichiometric in nitrogen content (Table 2) but has a large structural distortion - this suggests the structure type is not a standard rocksalt arrangement and that could be the reason for the very different phase behaviour relative to the chloroimide-derived samples. Ammonolysis of a polymer derived from $\left[\mathrm{Mo}_{2}\left(\mathrm{NMe}_{2}\right)_{6}\right]$ resulted in $\gamma-\mathrm{Mo}_{2} \mathrm{~N}$ at $450{ }^{\circ} \mathrm{C}$ and no mention of a structure distortion was made in the paper [38]. Between 800 and $1000{ }^{\circ} \mathrm{C}$ peaks due to the $\delta_{1}$-MoN phase were observed to grow in (Fig. 5), and at $1000{ }^{\circ} \mathrm{C}$ some decomposition to Mo metal was also observed.

Combustion analysis showed all the cubic samples to be nitrogen-rich relative to the $\gamma-\mathrm{Mo}_{2} \mathrm{~N}$ phase and that the nitrogen content decreased with increasing annealing temperature (Table 2). Samples produced at $800{ }^{\circ} \mathrm{C}$ and below contained trace amounts of carbon due to incomplete removal during decomposition of dimethylamide groups, but interestingly none was detected in the sample heated for $48 \mathrm{~h}$ at $500{ }^{\circ} \mathrm{C}$. This longer heating period also increased the nitrogen content, which can only mean it was oxidised by the ammonia during this process with hydrogen the likely by-product. Surface areas of all these samples were relatively low.

IR spectra were broadly the same as those observed from the chloroimide polymer, containing only a broad, weak band at 3530-3450 $\mathrm{cm}^{-1}$ due to surface NH groups. TEM images (Fig. 6) show a mixture of nanotubes and particles, this mixture is dominated by tubes in the samples annealed at 500 and $600{ }^{\circ} \mathrm{C}$, whilst very few tubes were observed at higher temperatures. Nanotubes of a conductive material such as molybdenum nitride could offer better electronic conduction pathways than more isotropic particles in supercapacitors electrodes, so these are interesting. However the low surface areas are less helpful for the intended application.

\subsection{Electrochemical behaviour of molybdenum nitride obtained from polymer precursors}

Molybdenum nitride powder samples were made into electrodes by deposition of inks formed with $20 \%$ acetylene black and 5\% PVDF onto titanium foil current collectors. Titanium foil exhibited currents of $0.05 \mathrm{~mA}$ or less under all conditions used and hence the capacitance due to the current collector was discounted. Cyclic voltammograms were collected at a series of scan rates to determine the charge storage capacity and the variation in this capacity with charge/discharge rate. Previous studies of molybdenum nitride-based supercapacitor electrodes had used sulphuric acid [18-22] or $\mathrm{KOH}$ [23] electrolytes. Here we evaluated electrodes in aqueous $\mathrm{H}_{2} \mathrm{SO}_{4}$ and $\mathrm{K}_{2} \mathrm{SO}_{4}$ solutions. 
Cyclic voltammograms of chloroimide-derived molybdenum nitride samples showed an electrolyte stability window from -0.1 to $-0.7 \mathrm{~V}$ vs $\mathrm{Hg} / \mathrm{HgSO}_{4}$ in $\mathrm{H}_{2} \mathrm{SO}_{4(\mathrm{aq})}$, and 0 to $-0.7 \mathrm{~V}$ in $\mathrm{K}_{2} \mathrm{SO}_{4(\mathrm{aq})}$, with strong sloping oxidation/reduction features observed outside of this window. CVs in this range with $\mathrm{H}_{2} \mathrm{SO}_{4}$ electrolyte show roughly parallel current profiles on the forward and backward scans, with the broad reduction feature at $c a-0.35 \mathrm{~V}$ becoming more apparent at slower scan rates (Fig. 7) but remaining at a similar potential throughout. The electrodes were sequentially cycled at a series of scan rates and importantly both the capacitance and the shape of the CVs was similar at the start and at the end of the process, with 140 cycles in between. Measured capacitances are listed in Table 3. In samples made at $600{ }^{\circ} \mathrm{C}$ and above our capacitances are slightly lower than those previously reported by Choi and Kumta for similar samples cycled in aqueous $\mathrm{KOH}\left(111 \mathrm{~F} \mathrm{~g}^{-1}\right.$ at 2 $\mathrm{mV} \mathrm{s}^{-1}$ from a $\gamma-\mathrm{Mo}_{2} \mathrm{~N}$ sample synthesised at $600{ }^{\circ} \mathrm{C}$ [23]), although they did report a $40 \%$ drop in capacity during cycling. At slow scan rates our highest surface area samples of $\delta_{1}$-MoN produced at $500{ }^{\circ} \mathrm{C}$ approach $200 \mathrm{~F} \mathrm{~g}^{-1}$, comparable with the highest values reported for molybdenum nitrides in the literature [18-24]. These capacitances fall by around 50\% at the fastest scan rates measured, $100 \mathrm{mV} \mathrm{s}^{-1}$.

Redox features were more obvious in CVs collected in $\mathrm{K}_{2} \mathrm{SO}_{4(\mathrm{aq})}$ electrolyte at slow scan rates (Fig. 7) and the capacitances of materials at these scan rates are higher (Table 4), with the highest measured values of $275 \mathrm{~F} \mathrm{~g}^{-1}$ exceeding previous reports [18-24]. However the reduction in capacitance at faster scan rates is more marked than that observed in $\mathrm{H}_{2} \mathrm{SO}_{4(\mathrm{aq})}$. This is accompanied by a shift in the redox features (reduction peak shifts from $-0.42 \mathrm{~V}$ at $2 \mathrm{mV} \mathrm{s}$ to -0.52 $\mathrm{V}$ at $25 \mathrm{mV} \mathrm{s}^{-1}$ and not observed at $100 \mathrm{mV} \mathrm{s}^{-1}$; oxidation peak shifts from $-0.35 \mathrm{~V}$ at $2 \mathrm{mV} \mathrm{s}^{-1}$ to $0.30 \mathrm{~V}$ at $10 \mathrm{mV} \mathrm{s}^{-1}$ and not observed at 25 or $100 \mathrm{mV} \mathrm{s}^{-1}$ ). At fast scan rates the $\mathrm{CVs}$ also exhibit a more strongly sloping overall profile (Fig. 7). Other authors have suggested that the conductivity and the radius of the hydrated electrolyte cation is a limitation on the high rate performance electrodes containing $\mathrm{K}_{(\mathrm{aq})}^{+}[22,47]$.

CVs of imide-derived samples in $\mathrm{H}_{2} \mathrm{SO}_{4(\mathrm{aq})}$ showed a potential window of $0.6 \mathrm{~V}$ as observed in the chloroimide-derived materials, but shifted to a slightly higher potential (0 to $-0.6 \mathrm{~V}$ ). In $\mathrm{K}_{2} \mathrm{SO}_{4(\mathrm{aq})}$ the larger 0 to $-0.7 \mathrm{~V}$ window found with the chloroimide-derived samples was used. The CVs also exhibited a larger number of redox features (Fig. 8) which were also more prominent, with three clear peaks in both the oxidation and the reduction sweeps. As with the chloroimide-derived materials the potentials at which these peaks were observed to vary little in $\mathrm{H}_{2} \mathrm{SO}_{4(\mathrm{aq})}$, with reduction peaks at $-0.16,-0.28$ and $-0.48 \mathrm{~V}$ at $2 \mathrm{mV} \mathrm{s}^{-1}$ compared with the same peaks at -0.19 , 0.31 and $-0.51 \mathrm{~V}$ at $100 \mathrm{mV} \mathrm{s}^{-1}$. In $\mathrm{K}_{2} \mathrm{SO}_{4(\mathrm{aq})}$ these were shifted to lower potentials $(-0.24,-0.40$ and $-0.58 \mathrm{~V}$ ) at $2 \mathrm{mV} \mathrm{s}^{-1}$ and further (to $-0.30,-0.55 \mathrm{~V}$ and off scale) at $100 \mathrm{mV} \mathrm{s}^{-1}$. This difference 
from the behaviour in acid may indicate a role for proton absorption or insertion in the redox processes, which may require extra steps in the neutral electrolyte and hence be slower. Also similarly, the overall profile of the higher rate $\mathrm{CVs}$ in $\mathrm{K}_{2} \mathrm{SO}_{4(\mathrm{aq})}$ is more sloped suggesting conductivity limitations. Capacitances in both electrolytes are listed in Tables 5 and 6.

The highest capacitance was observed in samples heated at $600{ }^{\circ} \mathrm{C}$, presumably because all amide and organic groups had been decomposed $(0 \% \mathrm{H})$. It is noteworthy that whilst these samples have lower capacitance than the chloroimide-derived samples they still store significant amounts of charge (highest value $161 \mathrm{~F} \mathrm{~g}^{-1}$ ) despite very low surface areas. The amount of charge stored is also not correlated to surface area. Overall these results, combined with the more prominent redox features in the CVs, suggest that pseudocapacitance (redox activity) takes a much more prominent role in the distorted rocksalt structure imide-derived molybdenum samples and that the effect of double layer capacitance is more significant in the chloroimide-derived materials. In future it may be possible to combine this more redox-active material with higher surface area and hence to combine the double layer capacitance and pseudocapacitance more effectively, this could result in significantly higher overall capacitance.

The stability of molybdenum nitride electrodes was also tested over a larger number of cycles at $100 \mathrm{mV} \mathrm{s}^{-1}$. The capacitance was well maintained through 1000 cycles (Fig. 9), with only the imide-derived material in acid electrolyte showing an initial drop in capacitance of $\sim 5 \%$ and even this system then stabilising.

\section{Conclusions}

Reactions of $\mathrm{MoCl}_{5}$ or $\mathrm{Mo}\left(\mathrm{NMe}_{2}\right)_{4}$ with ammonia followed by pyrolysis of the resultant polymer in ammonia at various temperatures result in $\gamma$ - or $\delta_{1}$ - molybdenum nitrides. Materials produced from $\mathrm{Mo}\left(\mathrm{NMe}_{2}\right)_{4}$ at moderate temperatures contain a high proportion of nanotubes and a distortion to the $\gamma-\mathrm{Mo}_{2} \mathrm{~N}$ rocksalt-type structure is observed. These materials show good electrochemical charge storage capability in aqueous $\mathrm{H}_{2} \mathrm{SO}_{4}$ and $\mathrm{K}_{2} \mathrm{SO}_{4}$ electrolytes. Cyclic voltammograms of $\mathrm{MoCl}_{5-}$ derived materials exhibit mainly double layer charging behaviour whereas those of molybdenum nitrides obtained from $\mathrm{Mo}\left(\mathrm{NMe}_{2}\right)_{4}$ contain strong redox features.

\section{Acknowledgements}

The authors thank The University of Southampton for a PG Scholarship to SIUS. 


\section{References}

[1] M.B. Kanoun, S. Goumri-Said, M. Jaouen, Phys. Rev. B 76 (2007) 134109.

[2] A.Y. Ganin, L. Kienle, G.V. Vajenine, J. Solid State Chem. 179 (2006) 2339-2348.

[3] C.L. Bull, P.F. McMillan, E. Soignard, K. Leinenweber, J. Solid State Chem.177 (2004) 1488-1492.

[4] D. McKay, J.S.J. Hargreaves, J.L. Rico, J.L. Rivera, X.-L. Sun, J. Solid State Chem. 181 (2008) 325-333.

[5] A.G. Cairns, J.G. Gallagher, J.S.J. Hargreaves, D. McKay, E. Morrison, J.L. Rico, K. Wilson, J. Alloys Cmpds. 479 (2009) 851-854.

[6] R. Marchand, F. Tessier, F.J. DiSalvo, J. Mater. Chem. 9 (1999) 297-304.

[7] H. He, H.X. Dai, K.Y. Ngan, C.T. Au, Catal. Lett. 71 (2001) 147-153.

[8] M.K. Neylon, S. Choi, H. Kwon, K.E. Curry, L.T. Thompson, Appl. Catal. A: General 183 (1999) 253-263.

[9] S.Z. Li, J.S. Lee, J. Catal., 1998, 178, 119-136; S.W. Gong, H.K. Chen, W. Li and B.Q. Li, Catal. Commun. 5 (2004) 621-624; T. Kadono, T. Kubota, Y. Okamoto, Catal. Today 87 (2003) 107-115.

[10] S.Z. Li, J. S. Lee, J. Catal. 1998, 173, 134-144; S.Z. Li, J.S. Lee, T. Hyeon, K.S. Suslick, Appl. Catal. A: General 184 (1999) 1-9; M. Nagai, Y. Goto, A. Miyata, M. Kiyoshi, K. Hada, K. Oshikawa, S. Omi, J. Catal. 182 (1999) 292-301.

[11] M. Nagae, T. Yoshio, Y. Takemoto, J. Takada, J. Am. Ceram. Soc.84 (2001) 1175-1177.

[12] K. Inumaru, T. Nishikawa, K. Nakamura, S. Yamanaka, Chem. Mater. 20 (2008) 4756-4761.

[13] P. Hones, R. Sanjines, F. Levy, Surf. Coatings Technol. 94-95 (1997) 398-402.

[14] R. Fix, R.G. Gordon, D.M. Hoffman, Thin Solid Films 288 (1996) 116-119.

[15] W.-F. Chen, K. Sasaki, C. Ma, A.I. Frenkel, N. Marinkovic, J.T. Muckerman, Y.M. Zhu, R.R. Adzic, Angew. Chem. Intl. Ed. 51 (2012) 6131-6135.

[16] P. Jampani, A. Manivannan, P.N. Kumta, ECS Interface 19 (2010) 57-62; S. Dong, X. Chen, X. Zhang, G. Cui, Coord. Chem. Rev. 257 (2013) 1946-1956.

[17] D. Choi, G.E. Blomgren, P.N. Kumta, Adv. Mater. 18 (2006) 1178-1182.

[18] D. Finello, New Developments in Ultracapacitor Technology, Report no. WL-TR-95-7024, Wright Laboratory, Eglin Air Force Base, Florida, USA, 1995.[

[19] S.L. Roberson, D. Finello, R.F. Davis, J. Appl. Electrochem. 29 (1999) 75-80.

[20] T.C. Liu, W.G. Pell, B.E. Conway, S.L. Roberson, J. Electrochem. Soc. 145 (1998) 1882-1888.

[21] C. Chen, D. Zhao, X. Wang, Mater. Chem. Phys. 97 (2006) 156-161.

[22] X.L. Li, Y. Xing, H. Wang, H.L. Wang, W.D. Wang, X.Y. Chen, Trans. Nonferrous Met. Soc. China, 19 (2009) 620-625.

[23] D. Choi, P. N. Kumta, J. Am. Ceram. Soc. 94 (2011) 2371-2378.

[24] K.H. Lee, Y.W. Lee, A.R. Ko, G.Z. Cao, K.W. Park, J. Am. Ceram. Soc. 96 (2013) 37-39.

[25] G. Hägg, Z. Phys. Chem. 1930, B7, 339-340.

[26] A. Wang, F. Capitain, V. Monnier, S. Matar, G. Demazeau, J. Mater. Synth. Proc. 5 (1997) 235-248.

[27] W. Lengauer, J. Crystal Growth 87 (1988) 295-298.

[28] R. Marchand, X. Gouin, F. Tessier, Y. Laurent, in: S.T. Oyama (Ed.) The Chemistry of Transition Metal Carbides and Nitrides, Blackie A\&P, Glasgow, 1996.

[29] S.T. Wang, X. Wang, Z.D. Zhang, Y.T. Qian, J. Mater. Sci. 38 (2003) 3473-3478.

[30] S.Z. Li, J.S. Lee, J. Catal. 162 (1996) 76-87; R.N. Panda, S. Kaskel, J. Mater. Sci. 41 (2006) 2465-2470.

[31] S.L. Roberson, D. Finello, R.F. Davis, Thin Solid Films 324 (1998) 30-36; V. Miikkulainen, M. Suvanto. T.A. Pakkanen, Chem. Mater. 19 (2007) 263-269; H. Kattelus, J. Koskenala, A. Nurmela, A. Niskanen, Microelec. Eng. 60 (2002) 97-105; Y. Wang, R.Y. Lin, Mater. Sci. Eng. B 112 (2004) 42-49; K. Inumaru, K. Baba, S. Yamanaka, Appl. Surf. Sci. 253 (2006) 2863-2869. 
[32] X.D. Zhao, K.J. Range, J. Alloys Cmpds. 296 (2000) 72-74; C.L. Bull, T. Kawashima, P.F. McMillan, D. Machon, O. Shebanova, D. Daisenberger, E. Soignard, E. Takayama-Muromachi, L.C. Chapon, J. Solid State Chem. 179 (2006) 1762-1767; T. Kawashima, E. Takayama-Muromachi, P.F. McMillan, Physica C 460 (2007) 651-652; K. Inumaru, T. Nishikawa, K. Nakamura, S. Yamanaka, Chem. Mater. 20 (2008) 4756-4761.

[33] B. Mazumder, A.L. Hector, J. Mater. Chem. 19 (2009) 4673-4686.

[34] P. Chirico, A.L. Hector, B. Mazumder, Dalton Trans. 39 (2010) 6092-6097; B. Mazumder, P. Chirico, A.L. Hector, Inorg. Chem. 47 (2008) 9684-9690.

[35] S.I.U. Shah, A.L. Hector, Top. Catal. 55 (2012) 950-954.

[36] S.T. Wang, Z.D. Zhang, Y.G. Zhang, Y.T. Qian, J. Solid State Chem. 177 (2004) 2756-2762.

[37] V. Miikkulainen, M. Suvanto, T.A. Pakkanen, Thin Solid Films 516 (2008) 6041-6047.

[38] D.V. Baxter, M.H. Chisholm, G.J. Gama, V.F. DiStasi, A.L. Hector, I.P. Parkin, Chem. Mater. 8 (1996) 1222-1228.

[39] A.W. Jackson, O. Shebanova, A.L. Hector, P.F. McMillan, J. Solid State Chem. 179 (2006) 1383-1393.

[40] A. Salamat, A.L. Hector, B.M. Gray, S.A.J. Kimber, P. Bouvier, P.F. McMillan, J. Amer. Chem. Soc. 135 (2013) 9503-9511.

[41] A.L. Hector, Chem. Soc. Rev. 36 (2007) 1745-1753; A.W. Jackson, A.L. Hector, J. Mater. Chem. 17 (2007) 10161022; S. Hassan, A.L. Hector, J.R. Hyde, A. Kalaji, D.C. Smith, Chem. Commun. (2008) 5304-5306; B.M. Gray, S.Hassan, A.L. Hector, A. Kalaji, B. Mazumder, Chem. Mater. 21 (2009) 4210-4215; S. Hassan, A.L. Hector, A. Kalaji, J. Mater. Chem. 21 (2011) 6370-6374.

[42] M.H. Chisholm, F.A. Cotton, B.A. Frenz, W.W. Reichert, L.W. Shive, B.R. Stults, J. Amer. Chem. Soc. 98 (1976) 4469-4476.

[43] A.C. Larson, R.B. Von Dreele, Generalized Structure Analysis System (GSAS), Los Alamos National Laboratory Report LAUR (2004) 86-748; R.B. Von Dreele, A.C. Larson, GSAS manual, LANSCE MS-H805, Los Alamos National Laboratory, NM87545 (2000); B.H. Toby, J. Appl. Cryst. 34 (2001) 210-213.

[44] ICSD accessed via The United Kingdom Chemical Database Service: D.A. Fletcher, R.F. McMeeking, D. Parkin, J. Chem. Inf. Comput. Sci. 36 (1996) 746-749.

[45] S. Brunauer; P.H. Emmett, E. Teller, J. Amer. Chem. Soc. 60 (1938) 309-319; E.P. Barrett, L.G. Joyner, P.P. Halenda, J. Am. Chem. Soc. 73 (1951) 373-380.

[46] J.W. Li, D. Dzivenko, A. Zerr, C. Fasel, Y.P. Zhou, R. Riedel, Z. Anorg. Allg. Chem. 631 (2005) 1449-1455.

[47] R.N. Reddy, R.G. Reddy, J. Power Sources 156 (2006) 700-704. 
Table 1 Refined parameters and analytical data for molybdenum nitride samples produced by pyrolysis of the chloroimide precursor.

\begin{tabular}{|c|c|c|c|c|c|c|}
\hline $\begin{array}{l}\text { Temperature } \\
{ }^{\circ} \mathrm{C} \\
\end{array}$ & $\begin{array}{l}\text { Heating } \\
\text { time /h }\end{array}$ & $a / \AA$ & $c / \AA$ & $\begin{array}{l}\text { Crystallite } \\
\text { size /nm }\end{array}$ & Composition & $\begin{array}{l}\text { Surface } \\
\text { area } / \mathbf{m}^{2} \mathbf{g}^{-1}\end{array}$ \\
\hline 1000 & 2 & $4.1967(7)$ & - & 22 & $\mathrm{MoN}_{0.62}$ & 2 \\
\hline 900 & 2 & $4.2017(10)$ & - & 16 & $\mathrm{MoN}_{0.62}$ & 2.8 \\
\hline 800 & 2 & $4.2044(8)$ & - & 20 & $\mathrm{MoN}_{0.64}$ & 8.9 \\
\hline 700 & 2 & $4.155(3)$ & - & 22 & $\mathrm{MoN}_{0.71}$ & 11.0 \\
\hline 600 & 2 & $4.176(3)$ & - & 24 & $\mathrm{MoN}_{1.00}$ & 18.5 \\
\hline 500 & 2 & $\begin{array}{l}2.866(3) \\
-{ }^{a}\end{array}$ & $\begin{array}{l}2.815(3) \\
-\end{array}$ & $\begin{array}{l}27 \\
-\end{array}$ & $\mathrm{MoN}_{1.13} \mathrm{Cl}_{0.08}$ & 70 \\
\hline 500 & 12 & $\begin{array}{l}4.170(7) \\
2.870(6)\end{array}$ & $2.810(6)$ & $\begin{array}{l}21 \\
23\end{array}$ & $\mathrm{MoN}_{1.02} \mathrm{Cl}_{0.08}$ & 37.3 \\
\hline 500 & 24 & $2.8536(14)$ & $2.7974(16)$ & 20 & $\mathrm{MoN}_{1.06} \mathrm{Cl}_{0.03}$ & 35.6 \\
\hline 500 & 48 & $2.8530(9)$ & $2.7955(11)$ & 32 & $\mathrm{MoN}_{1.08} \mathrm{Cl}_{0.05}$ & 4.8 \\
\hline
\end{tabular}

Cubic $\left(\gamma-\mathrm{Mo}_{2} \mathrm{~N}\right)$ patterns refined in $F m-3 m$, hexagonal $\left(\delta_{1}-\mathrm{MoN}\right)$ in $P-6 m 2$ using atom positions from ICSD [44] and nitrogen occupancies calculated from the combustion analysis data. $\mathrm{C}$ and $\mathrm{H}$ contents were $<0.10 \%$ throughout; stoichiometric MoN contains $12.73 \%$ N. ${ }^{\text {a }}$ Pattern too broad for Rietveld refinement.

Table 2 Refined parameters and analytical data for molybdenum nitride samples produced by pyrolysis of the imide precursor.

\begin{tabular}{lllllll}
\hline $\begin{array}{l}\text { Temperature } \\
\boldsymbol{I}^{\circ} \mathbf{C}\end{array}$ & $\begin{array}{l}\text { Heating } \\
\text { time } / \mathbf{h}\end{array}$ & $\boldsymbol{a} / \mathbf{\AA}$ & $\boldsymbol{c} / \mathbf{\AA}$ & $\begin{array}{l}\text { Crystallite } \\
\text { size } / \mathbf{m m}\end{array}$ & Composition & $\begin{array}{l}\text { Surface } \\
\mathbf{a r e a} / \mathbf{m}^{\mathbf{2}} \mathbf{g}^{-\mathbf{1}}\end{array}$ \\
\hline 1000 & 2 & $4.2118(8)$ & - & 14 & $\mathrm{MoN}_{0.58}$ & 2 \\
& & $2.8627(6)$ & $2.8266(7)$ & 28 & & \\
900 & 2 & $4.175(5)$ & - & 4.4 & $\mathrm{MoN}_{0.80}$ & 2.8 \\
& & $2.863(8)$ & $2.807(8)$ & 14 & & \\
800 & 2 & $4.14^{\mathrm{a}}$ & - & 8.8 & $\mathrm{MoN}_{0.84} \mathrm{C}_{0.03}$ & 3.1 \\
700 & 2 & $4.06^{\mathrm{a}}$ & - & 6 & $\mathrm{MoN}_{0.81} \mathrm{C}_{0.03}$ & 4.9 \\
600 & 2 & $4.07^{\mathrm{a}}$ & - & 4 & $\mathrm{MoN}_{0.83} \mathrm{C}_{0.05}$ & 9.8 \\
500 & 2 & $4.04^{\mathrm{a}}$ & - & 4 & $\mathrm{MoN}_{0.74} \mathrm{C}_{0.08} \mathrm{H}_{0.6}$ & 9 \\
500 & 48 & $4.08^{\mathrm{a}}$ & - & 4 & $\mathrm{MoN}_{1.02}$ & 8 \\
\hline
\end{tabular}

Patterns at 1000 and $900{ }^{\circ} \mathrm{C}$ refined using cubic $\left(\gamma-\mathrm{Mo}_{2} \mathrm{~N}, F m-3 m\right)$ and hexagonal $\left(\delta_{1}-\mathrm{MoN}, P-6 m 2\right)$ structure models with atom positions from ICSD [44] and nitrogen occupancies calculated from the combustion analysis data. $\mathrm{C}$ and $\mathrm{H}$ contents were $<0.10 \%$ where not stated otherwise; stoichiometric MoN contains $12.73 \%$ N. ${ }^{a}$ Pattern not subjected to Rietveld refinement due to the structure distortion described in the text, the given lattice parameter is an average cubic value for the observed reflections. 
Table 3 Specific capacitance $\left(\mathrm{F} \mathrm{g}^{-1}\right)$ in $0.5 \mathrm{M} \mathrm{H}_{2} \mathrm{SO}_{4}$ of molybdenum nitride samples obtained by pyrolysis of the chloroimide precursor under the conditions shown.

\begin{tabular}{|c|c|c|c|c|c|c|c|c|c|c|}
\hline \multirow{2}{*}{$\begin{array}{l}\text { Scan rate }\left(\mathrm{mV} \mathrm{s}^{-1}\right) \\
\text { Scan number }\end{array}$} & \multicolumn{2}{|l|}{100} & \multicolumn{2}{|l|}{25} & \multicolumn{2}{|l|}{10} & \multicolumn{2}{|l|}{2} & \multicolumn{2}{|l|}{100} \\
\hline & 1 & 10 & 1 & 10 & 1 & 10 & 1 & 10 & 1 & 100 \\
\hline $500^{\circ} \mathrm{C}, 2 \mathrm{~h}$ & 113 & 109 & 158 & 146 & 167 & 160 & 202 & 202 & 106 & 102 \\
\hline $500{ }^{\circ} \mathrm{C}, 12 \mathrm{~h}$ & 85 & 85 & 113 & 106 & 156 & 162 & 193 & 189 & 86 & 81 \\
\hline $500^{\circ} \mathrm{C}, 24 \mathrm{~h}$ & 87 & 87 & 126 & 120 & 141 & 138 & 163 & 163 & 90 & 90 \\
\hline $500^{\circ} \mathrm{C}, 48 \mathrm{~h}$ & 37 & 36 & 44 & 41 & 46 & 41 & 50 & 48 & 31 & 25 \\
\hline $600^{\circ} \mathrm{C}, 2 \mathrm{~h}$ & 58 & 56 & 71 & 69 & 76 & 63 & 85 & 81 & 48 & 41 \\
\hline $700^{\circ} \mathrm{C}, 2 \mathrm{~h}$ & 47 & 4 & 49 & 48 & 51 & 49 & 58 & 51 & 31 & 30 \\
\hline $800^{\circ} \mathrm{C}, 2 \mathrm{~h}$ & 22 & 20 & 23 & 23 & 25 & 23 & 31 & 30 & 17 & 15 \\
\hline $900^{\circ} \mathrm{C}, 2 \mathrm{~h}$ & 16 & 15 & 17 & 14 & 18 & 18 & 24 & 24 & 12 & 12 \\
\hline $1000^{\circ} \mathrm{C}, 2 \mathrm{~h}$ & 15 & 12 & 17 & 17 & 17 & 18 & 26 & 26 & 14 & 15 \\
\hline
\end{tabular}

Table 4 Specific capacitance $\left(\mathrm{F} \mathrm{g}^{-1}\right)$ in $0.5 \mathrm{M} \mathrm{K}_{2} \mathrm{SO}_{4}$ of molybdenum nitride samples obtained by pyrolysis of the chloroimide precursor under the conditions shown.

\begin{tabular}{l|lll|ll|ll|ll|ll}
\hline $\begin{array}{l}\text { Scan rate }(\mathbf{m V ~ s} \\
\text { Scan number }\end{array}$ & $\mathbf{1 0 0}$ & $\mathbf{1}$ & $\mathbf{1 0}$ & $\mathbf{1}$ & $\mathbf{1 0}$ & $\mathbf{1}$ & $\mathbf{1 0}$ & $\mathbf{1}$ & $\mathbf{1 0}$ & $\mathbf{1}$ & $\mathbf{1 0 0}$ \\
\hline $500{ }^{\circ} \mathrm{C}, 2 \mathrm{~h}$ & 85 & 85 & 158 & 158 & 214 & 214 & 275 & 275 & 82 & 82 \\
$500{ }^{\circ} \mathrm{C}, 12 \mathrm{~h}$ & 83 & 83 & 114 & 107 & 156 & 161 & 241 & 245 & 86 & 84 \\
$500{ }^{\circ} \mathrm{C}, 24 \mathrm{~h}$ & 84 & 84 & 151 & 146 & 188 & 181 & 250 & 241 & 78 & 76 \\
$500{ }^{\circ} \mathrm{C}, 48 \mathrm{~h}$ & 26 & 26 & 37 & 37 & 49 & 49 & 67 & 67 & 25 & 24 \\
$600{ }^{\circ} \mathrm{C}, 2 \mathrm{~h}$ & 64 & 62 & 87 & 82 & 93 & 89 & 112 & 110 & 59 & 57 \\
$700{ }^{\circ} \mathrm{C}, 2 \mathrm{~h}$ & 59 & 52 & 72 & 68 & 92 & 83 & 97 & 93 & 52 & 48 \\
$800{ }^{\circ} \mathrm{C}, 2 \mathrm{~h}$ & 35 & 32 & 39 & 39 & 41 & 37 & 53 & 50 & 31 & 30 \\
$900{ }^{\circ} \mathrm{C}, 2 \mathrm{~h}$ & 34 & 32 & 38 & 38 & 42 & 40 & 49 & 49 & 26 & 26 \\
$1000{ }^{\circ} \mathrm{C}, 2 \mathrm{~h}$ & 29 & 27 & 37 & 33 & 42 & 40 & 48 & 48 & 24 & 24 \\
\hline
\end{tabular}


Table 5 Specific capacitance $\left(\mathrm{F} \mathrm{g}^{-1}\right)$ in $0.5 \mathrm{M} \mathrm{H}_{2} \mathrm{SO}_{4}$ of molybdenum nitride samples obtained by pyrolysis of the imide precursor under the conditions shown.

\begin{tabular}{|c|c|c|c|c|c|c|c|c|c|c|}
\hline \multirow{2}{*}{$\begin{array}{l}\text { Scan rate }\left(\mathrm{mV} \mathrm{s}^{-1}\right) \\
\text { Scan number }\end{array}$} & \multicolumn{2}{|c|}{100} & \multicolumn{2}{|l|}{25} & \multicolumn{2}{|l|}{10} & \multicolumn{2}{|l|}{2} & \multicolumn{2}{|l|}{100} \\
\hline & 1 & 10 & 1 & 10 & 1 & 10 & 1 & 10 & 1 & 100 \\
\hline $500^{\circ} \mathrm{C}, 2 \mathrm{~h}$ & 37 & 37 & 53 & 51 & 58 & 58 & 70 & 63 & 32 & 31 \\
\hline $500{ }^{\circ} \mathrm{C}, 48 \mathrm{~h}$ & 64 & 63 & 71 & 69 & 86 & 85 & 107 & 107 & 61 & 60 \\
\hline $600^{\circ} \mathrm{C}, 2 \mathrm{~h}$ & 74 & 69 & 92 & 92 & 109 & 109 & 148 & 148 & 69 & 67 \\
\hline $700^{\circ} \mathrm{C}, 2 \mathrm{~h}$ & 23 & 21 & 25 & 23 & 30 & 27 & 32 & 31 & 19 & 18 \\
\hline $800^{\circ} \mathrm{C}, 2 \mathrm{~h}$ & 22 & 22 & 25 & 24 & 24 & 24 & 30 & 30 & 17 & 16 \\
\hline $900^{\circ} \mathrm{C}, 2 \mathrm{~h}$ & 18 & 18 & 22 & 22 & 26 & 26 & 34 & 34 & 17 & 17 \\
\hline $1000^{\circ} \mathrm{C}, 2 \mathrm{~h}$ & 12 & 11 & 14 & 11 & 16 & 16 & 18 & 18 & 10 & 9 \\
\hline
\end{tabular}

Table 6 Specific capacitance $\left(\mathrm{F} \mathrm{g}^{-1}\right)$ in $0.5 \mathrm{M} \mathrm{K}_{2} \mathrm{SO}_{4}$ of molybdenum nitride samples obtained by pyrolysis of the imide precursor under the conditions shown.

\begin{tabular}{|c|c|c|c|c|c|c|c|c|c|c|}
\hline \multirow{2}{*}{$\begin{array}{l}\text { Scan rate }\left(\mathrm{mV} \mathrm{s}^{-1}\right) \\
\text { Scan number }\end{array}$} & \multicolumn{2}{|c|}{100} & \multicolumn{2}{|l|}{25} & \multicolumn{2}{|l|}{10} & \multicolumn{2}{|l|}{2} & \multicolumn{2}{|c|}{100} \\
\hline & 1 & 10 & 1 & 10 & 1 & 10 & 1 & 10 & 1 & 100 \\
\hline $500^{\circ} \mathrm{C}, 2 \mathrm{~h}$ & 50 & 50 & 55 & 54 & 60 & 60 & 72 & 72 & 39 & 39 \\
\hline $500^{\circ} \mathrm{C}, 48 \mathrm{~h}$ & 62 & 60 & 65 & 63 & 72 & 72 & 91 & 91 & 57 & 55 \\
\hline $600^{\circ} \mathrm{C}, 2 \mathrm{~h}$ & 74 & 67 & 96 & 93 & 119 & 119 & 161 & 161 & 65 & 61 \\
\hline $700^{\circ} \mathrm{C}, 2 \mathrm{~h}$ & 25 & 23 & 26 & 25 & 31 & 31 & 47 & 47 & 23 & 23 \\
\hline $800^{\circ} \mathrm{C}, 2 \mathrm{~h}$ & 19 & 18 & 21 & 20 & 23 & 23 & 35 & 33 & 20 & 20 \\
\hline $900^{\circ} \mathrm{C}, 2 \mathrm{~h}$ & 16 & 14 & 26 & 26 & 28 & 28 & 33 & 33 & 14 & 14 \\
\hline $1000^{\circ} \mathrm{C}, 2 \mathrm{~h}$ & 16 & 14 & 18 & 18 & 21 & 21 & 25 & 25 & 12 & 10 \\
\hline
\end{tabular}



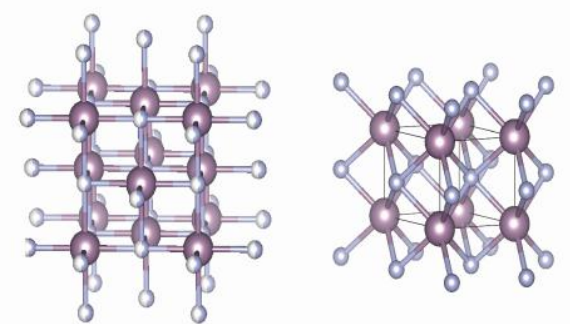

$\mathrm{Y}-\mathrm{Mo}_{2} \mathrm{~N}$

$\delta_{1}-\mathrm{Mo}_{2} \mathrm{~N}$

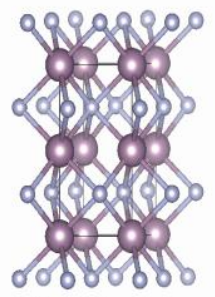

$\delta_{2}-\mathrm{Mo}_{2} \mathrm{~N}$

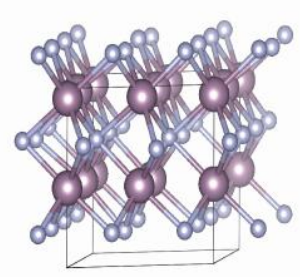

$\delta_{3}-\mathrm{Mo}_{2} \mathrm{~N}$

Fig. 1 The structures of some molybdenum nitride phases

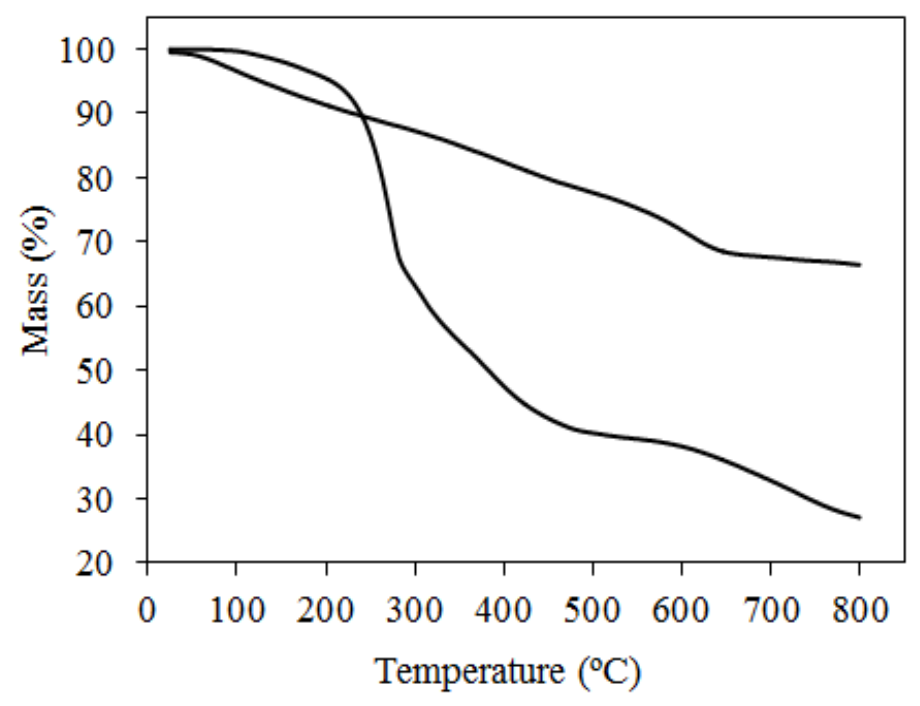

Fig. 2 TGA profiles for the thermal decomposition of the chloroimide (bottom) and imide (top) polymer precursors under flowing nitrogen. 


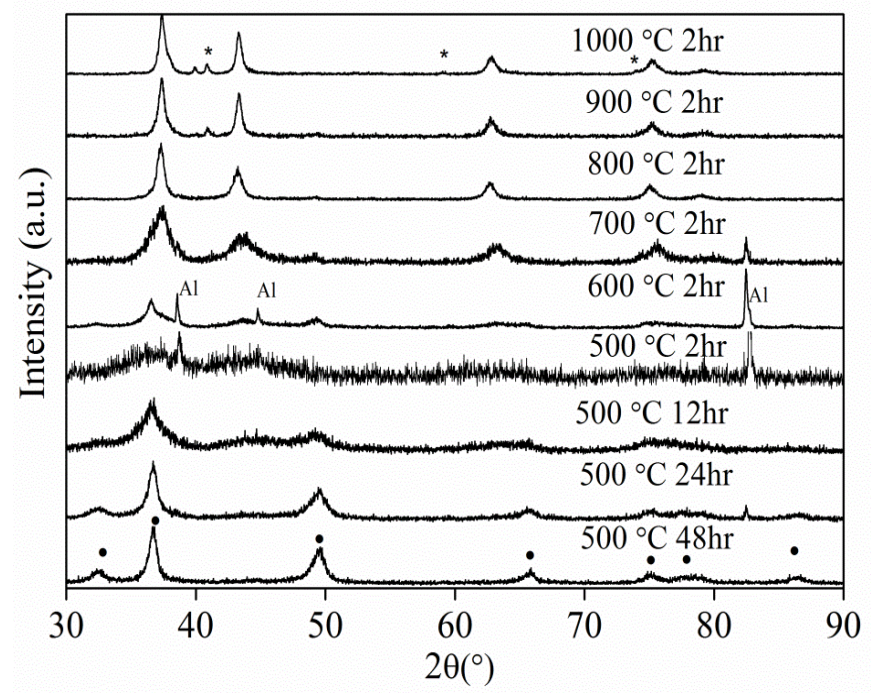

Fig. 3 PXD patterns of chloroimide-derived molybdenum nitride samples heated in ammonia under the labelled conditions. Closed circles show the positions of reflections due to $\delta_{1}, \mathrm{MoN}$ and asterisks the reflections of Mo metal. Peaks from the Al sample holder are labelled as Al. 

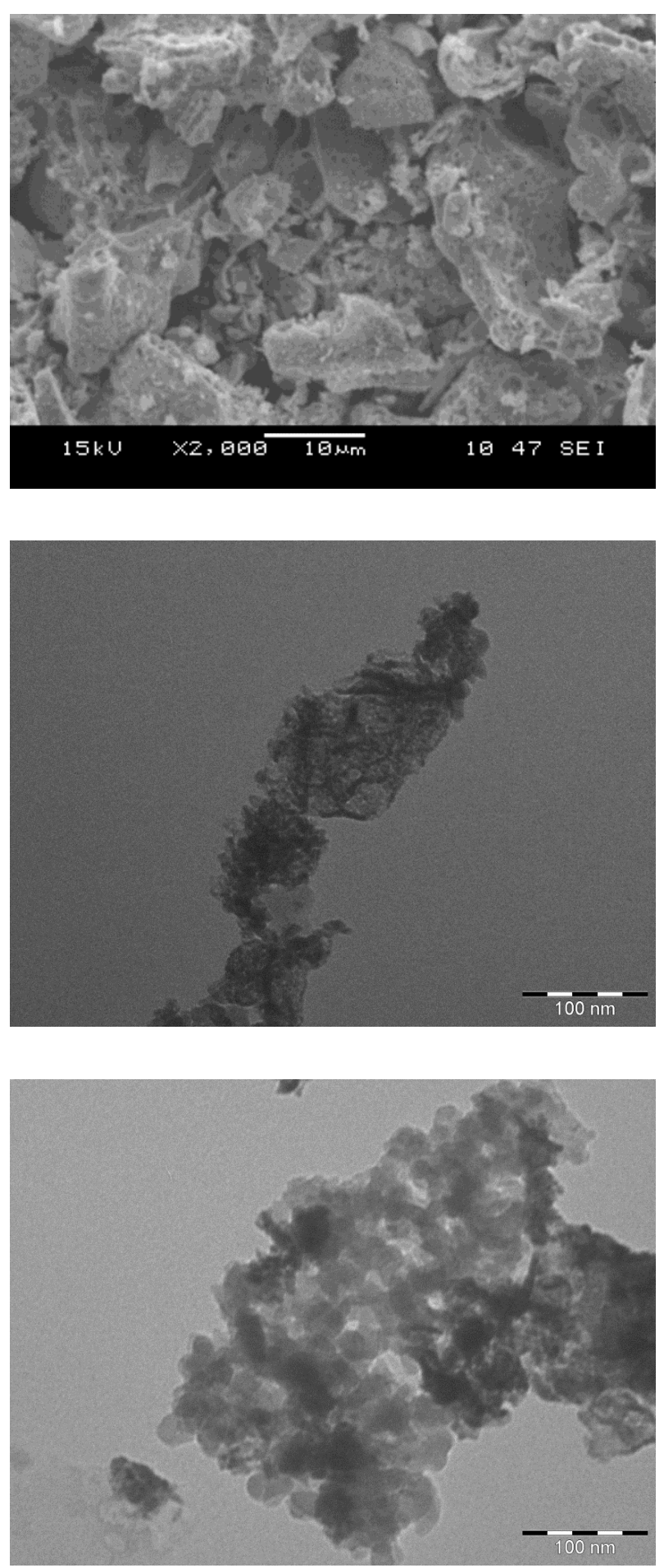

Fig. 4 SEM image of $\delta_{1}$-MoN produced at $800{ }^{\circ} \mathrm{C}$ (top), and TEM images of $\delta_{1}$-MoN produced by heating at $500{ }^{\circ} \mathrm{C}$ for $2 \mathrm{~h}$ (middle) or at $700{ }^{\circ} \mathrm{C}$ for $2 \mathrm{~h}$ (bottom). 


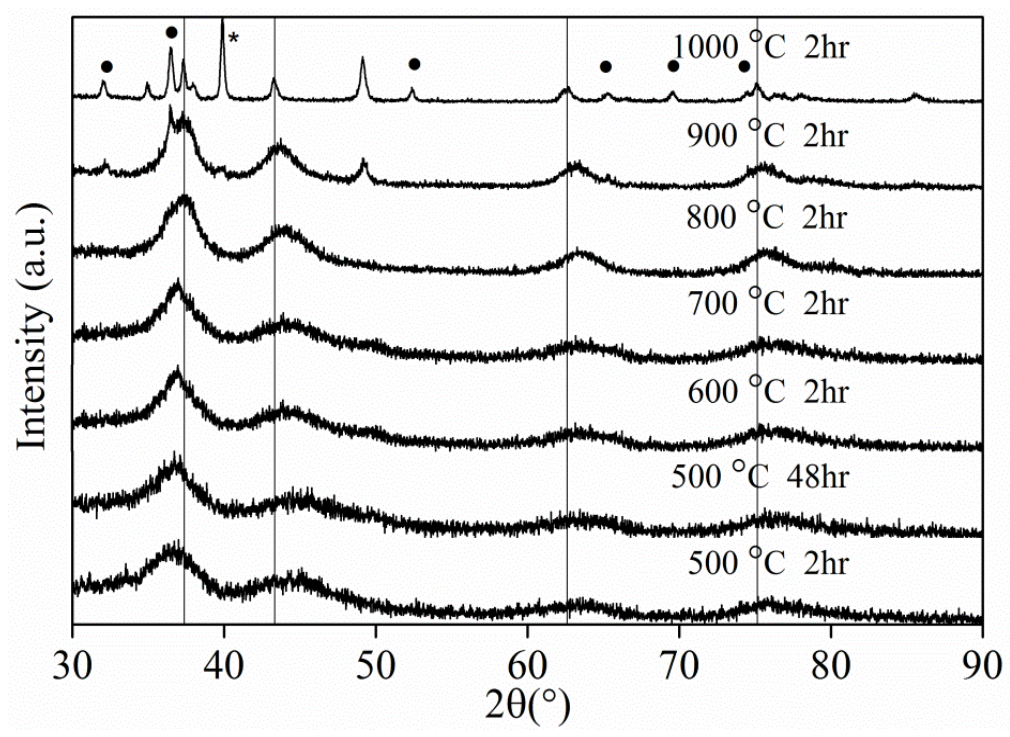

Fig. 5 XRD patterns of molybdenum nitride samples produced by heating the imide polymer precursor in ammonia under the conditions shown. The vertical lines show the reflection positions of cubic MoN at $900{ }^{\circ} \mathrm{C}$, closed circles are the positions of $\delta_{1}-\mathrm{MoN}$ reflections and the asterisk shows a peak due to molybdenum metal. 

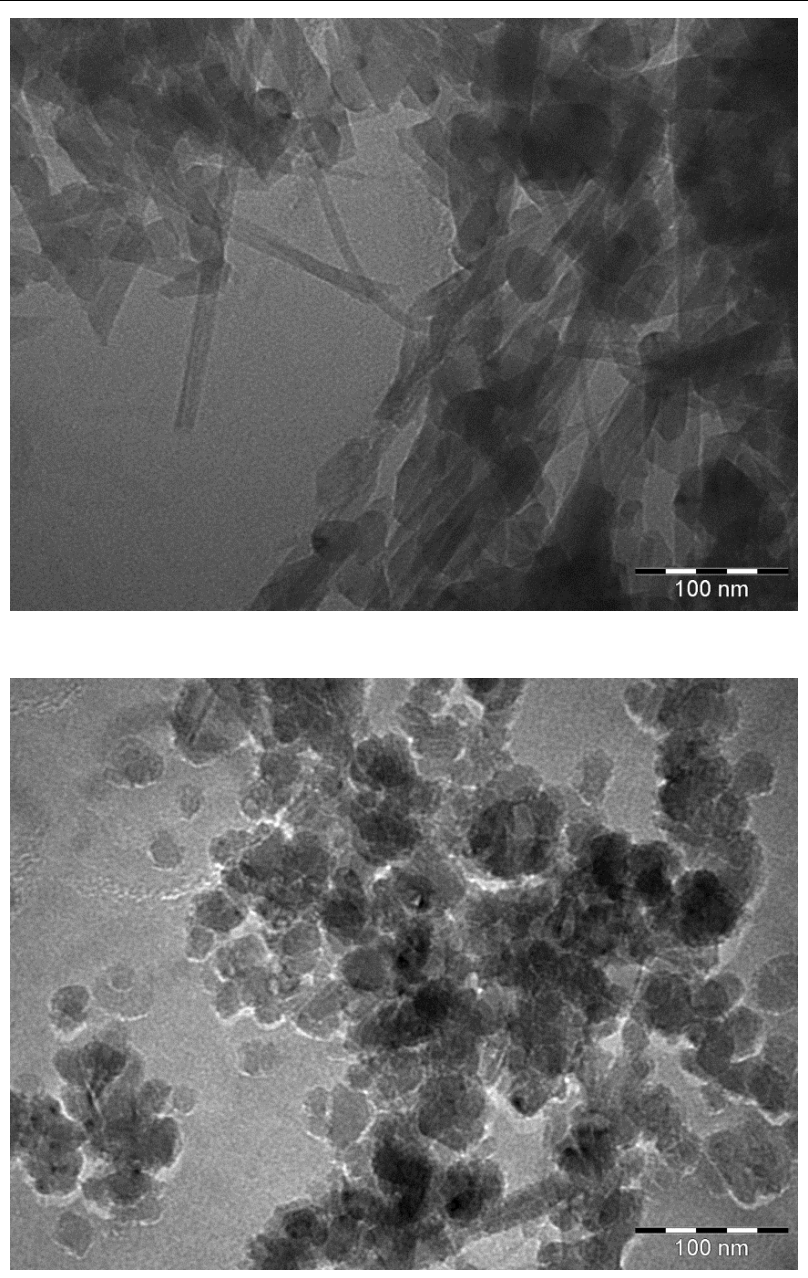

Fig. 6 TEM images of molybdenum nitride samples annealed at $500{ }^{\circ} \mathrm{C}$ for $2 \mathrm{~h}$ (top) and at $700{ }^{\circ} \mathrm{C}$ for $2 \mathrm{~h}$ (bottom) 

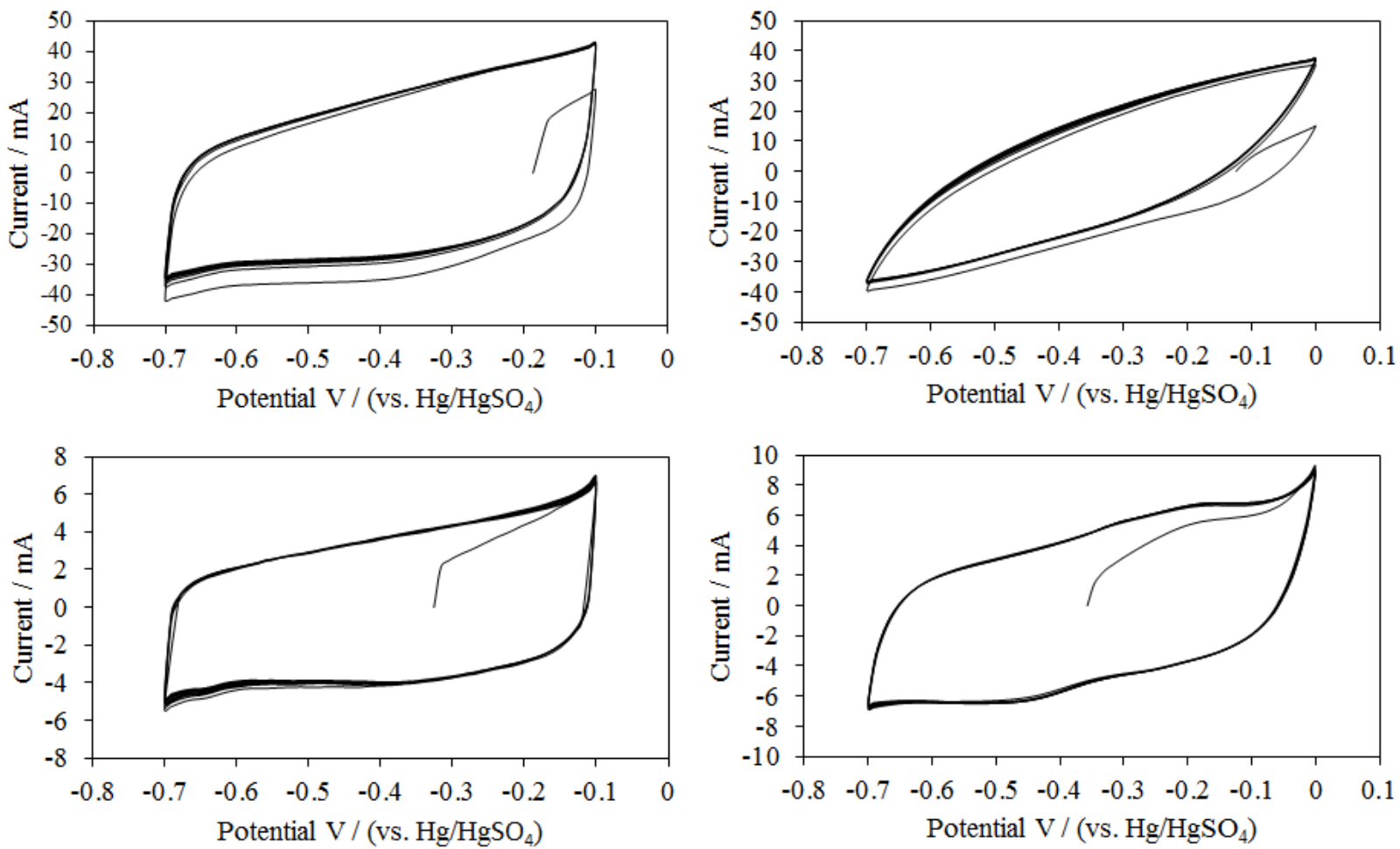

Fig. 7 Cyclic voltammograms of chloroimide-derived molybdenum nitride (heating conditions: $2 \mathrm{~h}$ at $500{ }^{\circ} \mathrm{C}$ ) at scan rates of 100 (top) and 10 (bottom) $\mathrm{mV} \mathrm{s}^{-1}$ in $0.5 \mathrm{M} \mathrm{H}_{2} \mathrm{SO}_{4(\mathrm{aq})}$ (left) and $0.5 \mathrm{M} \mathrm{K}_{2} \mathrm{SO}_{4 \text { (aq) }}$ (right) electrolytes. 

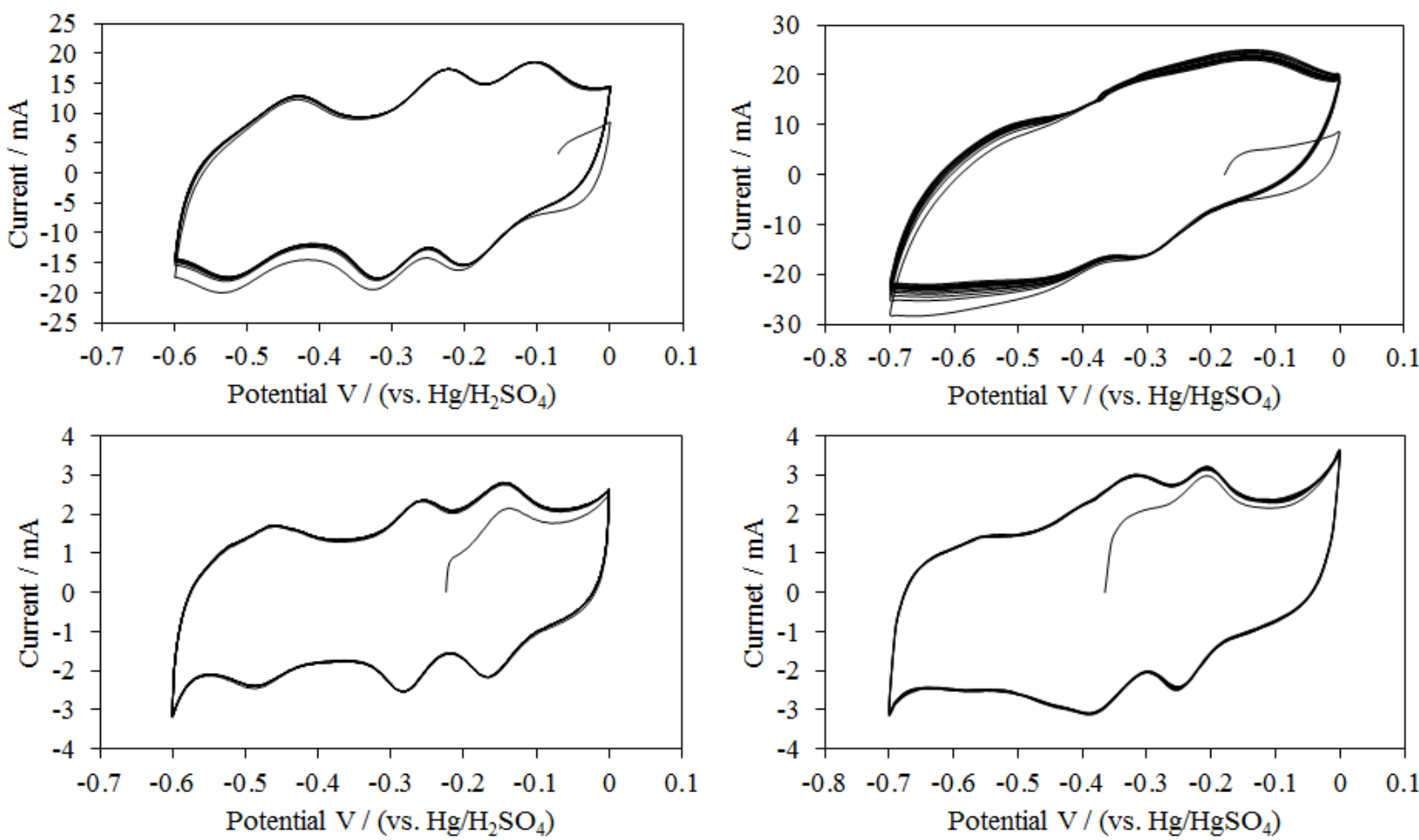

Fig. 8 Cyclic voltammograms of imide-derived molybdenum nitride (heating conditions: $2 \mathrm{~h}$ at $600{ }^{\circ} \mathrm{C}$ ) at scan rates of 100 (top) and 10 (bottom) $\mathrm{mV} \mathrm{s}^{-1}$ in $\mathrm{H}_{2} \mathrm{SO}_{4(\mathrm{aq})}$ (left) and $\mathrm{K}_{2} \mathrm{SO}_{4 \text { (aq) }}$ (right) electrolytes.

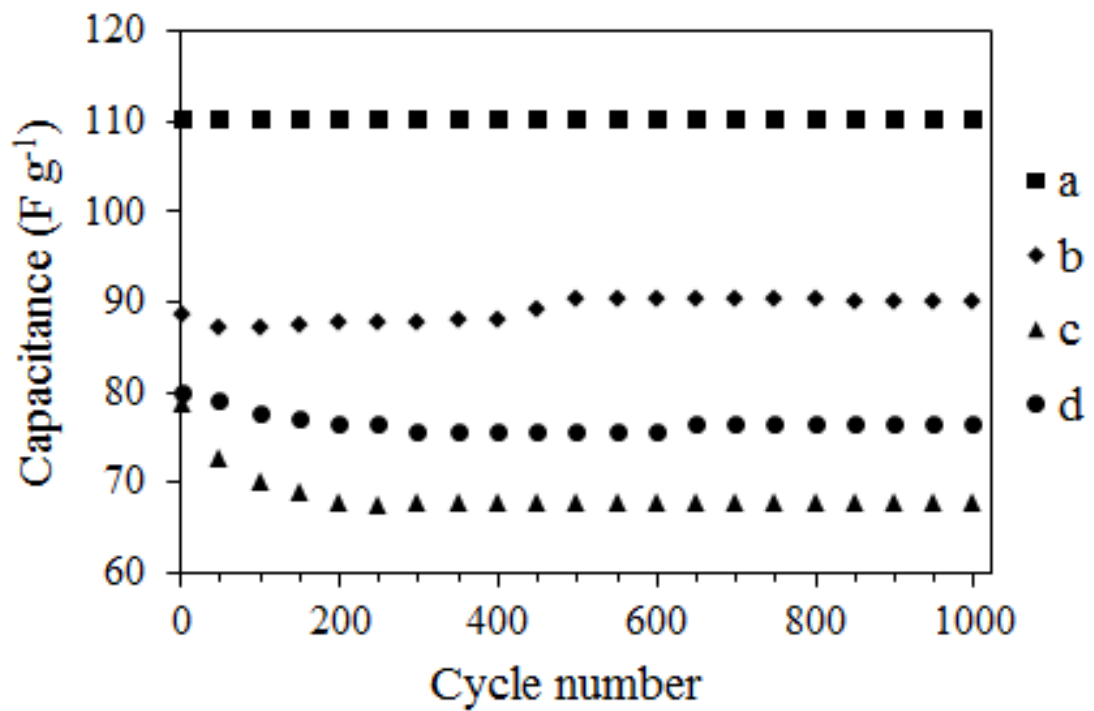

Fig. 9 Variation of specific capacitance of chloroimide-derived molybdenum nitride (heating conditions $500{ }^{\circ} \mathrm{C}$ for $2 \mathrm{~h}$ ) over 1000 charge/discharge cycles at $100 \mathrm{mV} \mathrm{s}^{-1}$ in $\mathrm{H}_{2} \mathrm{SO}_{4}$ (a) and $\mathrm{K}_{2} \mathrm{SO}_{4}$ (b) electrolyte, and imide-derived molybdenum nitride under the same conditions $\left(\mathrm{H}_{2} \mathrm{SO}_{4}(\mathrm{c})\right.$ and $\left.\mathrm{K}_{2} \mathrm{SO}_{4}(\mathrm{~d})\right)$. 